\title{
Cognition in (inter)action: multimodal metaphors produced during a lesson of German as a Foreign Language
}

\author{
Cognição em (inter)ação: metáforas multimodais produzidas durante uma aula de Alemão como Língua \\ Estrangeira
}

\section{Adriana Fernandes Barbosa}

Universidade Federal de Minas Gerais - UFMG - Belo Horizonte - Minas Gerais - Brasil

\begin{abstract}
$\longrightarrow$
Resumo: O artigo explora como a metaforicidade se expressa através de metáforas multimodais produzidas por um professor falante nativo de alemão e aprendizes brasileiros de Alemão como Língua Estrangeira ao discutir possíveis significados metafóricos da preposição e prefixo verbal über. A aula, que foi ministrada para alunos de graduação de uma universidade brasileira, foi filmada. As interações foram transcritas utilizando as convenções GAT 2 e os gestos foram descritos com base em Cienki (2010). Com base nos conceitos de Fluência Conceitual, de Danesi (1995), bem como os aspectos dinâmicos da metaforicidade de Müller e Cienki (2009), a análise revelou como o pensamento metafórico é realmente corporificado e como tal corporeidade pode ser explorada em sala de aula.
\end{abstract}

Palavras-chave: metáforas multimodais, preposições e prefixos verbais, Alemão como Língua Estrangeira.

Abstract: The article explore how metaphoricity is expressed through the multimodal metaphors produced by a German-native-speaker teacher and Brazilian learners of German as a Foreign Language when discussing possible metaphorical meanings of the preposition and verbal prefix über. The lesson, which was taught for undergraduates at a Brazilian university, was videotaped. The interactions were transcribed using the conventions GAT 2 and gestures were described based on Cienki (2010). Based on the concepts of Conceptual Fluency by Danesi (1995) as well as the dynamic aspects of metaphoricity by Müller and Cienki (2009), the analysis revealed how metaphor thinking is indeed embodied and how such embodiment can be explored in the classroom.

Keywords: multimodal metaphors, prepositions and verbal prefixes, German as a Foreign Language. 


\section{Introdução}

For cognitive linguists, language is considered an integral part of our cognition. Therefore, learning a new language is also a cognitive process. Recent research in the field of German as a Foreign Language (DaF) shows an improvement in the learning of prepositions when applying a cognitive approach (SCHELLER, 2008, GRASS, 2014, ROCHE and SCHELLER, 2014). Danesi (2008, p. 231) has already advocated for the inclusion of the target language's cognitive and sociocultural system in Second Language Teaching so that learners have a systematic, sequential and integrated approach to the system.

Considering that some German verbal prefixes have highly metaphorical meaning, DaF-learners might face some difficulty at learning them, especially when producing language (BELLAVIA, 2007). Therefore, teaching cognitive aspects of a second language (L2) is a way to help advanced learners understand better as well as retain lexical units (LITTLEMORE and LOW, 2006; BELLAVIA, 2007; BOERS and LINDSTROMBERG, 2008; LITTLEMORE, 2009). Moreover, learners tend to recognize and analyses conceptual aspects, such as metaphorical meanings, of a new lexical unit when learning a new language (LITTLEMORE, 2008, 2009; PICKEN, 2007).

Therefore, the study of multimodal metaphors as well as their degree of metaphoricity in teacherstudent interactions will help us understand the process of metaphorical meaning negotiation in the classroom and shed some light on the role of conceptual fluency in Foreign Language Teaching and Learning. According to Cienki (2008, p.16) "[g]esture can provide an important locus for cognitive linguistic research on metaphor because it physically manifests the tenet that (many) metaphors are grounded in embodied action". Additionally, metaphoricity is a measurement of how evident a metaphor for the interlocutors in an interaction can be and gestures are the tool used by interlocutor to make metaphors more evident (MÜLLER and CIENKI, 2009; MÜLLER and TAG, 2010).

The article focuses on the analysis of multimodal metaphors produced by a German-nativespeaker teacher and Brazilian learners of German as a Foreign Language when discussing possible metaphorical meanings of the preposition and verbal prefix über. The analysis offered insights not only to the context of production but also to the understanding of these metaphorical meanings.

\section{Conceptual fluency, metaphoricity and multimodal metaphor in the FL teaching and learning}

Considering the application of Cognitive Linguistics in Foreign Language Teaching (FLT), Lakoff and Johnson's (1980) Cognitive Metaphor Theory (CMT) is one of the most important theoretical foundations alongside Langacker's (1987, 1991) Cognitive Grammar. One of the exponents of a cognitive-oriented approach to FLT is Low (1988), who discusses the metaphorical language functions and pedagogical implications for didactic material. Radden (1994), in turn, illustrates the importance of using image schemas and conceptual metaphors to explain the systematic coherence of metaphorical expressions in the target language. His argument is based on the idea that a considerable part of the lexicon is iconically - schematically - motivated, and therefore it is cognitively easier for the learners to understand these lexical terms. Therefore, one can say that the metaphorical meanings of German verbs, whose prefixes are formed by prepositions, were motivated by the concrete meaning of these prepositions. This metaphorical motivation can be explained to learners in order to help them recognize meaning patterns in the L2. Bellavia (2007) shows that the knowledge of cognitive principles that regulate the semantic structure of language allows learners to interact with a more limited set of rules that can be used in a larger number of linguistic phenomena. 
Danesi (1995) was the first author to mention a distinction between linguistic competence and what he calls conceptual competence or conceptual fluency. He claims that language learners may produce L2 with a high degree of verbal fluency (grammatical and communicative competence), but they lack conceptual appropriateness. In his words:

students "speak" with the formal structures of the target language, but they "think" in terms of their native conceptual system: i.e., students typically use target language words and structures as "carriers" of their own native language concepts (DANESI, 1995, p.5).

On the other hand, if students can match their verbal fluency to the conceptual knowledge in the $L 2$, they become conceptually fluent. Additionally, "to be conceptually fluent in a language is to know, in large part, how that language 'reflects' or encodes concepts on the basis of metaphorical reasoning" (DANESI, 1995 , p.5). Therefore, as metaphorical reasoning is part of the native speaker competence, then it should be taught like other competences, such as grammatical and communication.

Given the importance of the conceptual metaphor in the process of learning a foreign language, the language embodiment in teachers and students must be considered when analyzing the process of teaching and/or learning metaphors, as such embodiment will certainly be reflected in the teacher-student interaction when negotiation of meaning takes place, since such negotiation is made mostly through conversation. Cienki (2010) claims that gestures are the most important tool to access the process of metaphorical thinking, since gestures are the representation of language embodiment itself. Müller and Cienk (2009) define metaphors that occurs in face-to-face interaction as monomodal or multimodal metaphors. According to them, when the source and target domain of a metaphor are expressed in only one modality (only oral/aural or only visual/spatial modality), monomodal metaphor occurs. On the other hand, when the source and target domains of a metaphor are represented in different modalities, a multimodal metaphor is produced. In other words, when speakers produce a gesture simultaneously to the linguistic metaphor, or a verbo- gestural metaphor, this is a multimodal metaphor. Müller and Cienk (2009) also point out that studying multimodal metaphors help us reconsider the static view of CMT and see metaphor rather as a dynamic phenomenon with different degrees of metaphoricity. Therefore, monomodal metaphor would be less evident to speakers during an interaction than verbogestural or multimodal metaphors, since the use of different modalities bring the metaphoricity to the focus of the conversation and make the metaphor more evident. In other words, when using a verbogestural metaphor, the speaker expresses the target domain verbally, but the source domain is represented by the gesture. This visual representation is both a proof of language embodiment and an interactional strategy to bring metaphoricity to the focus of the conversation.

Müller and Tag (2010) also discuss this dynamic view of metaphor and relates verbo-gestural metaphors to cognitive processes such as foregrounding and profiling. Following iconicity, interactive as well as semantic and syntactic principals, they suggest different strategies used by speakers to make gestures more salient to their interlocutors which foreground metaphoricity during interaction. According to them, by making a verbogestural compound more evident to the interlocutor, the speaker active the metaphoricity. Therefore, Müller and Tag, (2010, p.6) state: "what is interactively foregrounded is where the focus of attention sits, it is also cognitively active".

Moreover, the analysis of metaphorical gestures contributes to solve the problem of circularity of Conceptual Metaphor Theory, for they are visual evidences of metaphor mapping.

Thereby, one important contribution of metaphor gesture studies to cognitive metaphor theory lies in the support provided through visible acting out of gestures for the indication of the existence of conceptual metaphors, discouraging the argument of the linguistic circularity as evidence for the existence of conceptual structures guiding cognition. (SCHRÖDER, 2018, p.496).

In the following section I will analyze multimodal metaphors produced by teachers and 
learners of German as a Foreign Language as they discuss in class the possible meanings of über in different contexts.

\section{Analysis}

The analyses were based on data collected in 2014 during a DaF-lesson taught for undergraduates at a Brazilian university. The teacher is a native speaker of German and the students were all Brazilian. Their language level can be placed on level A2 of the European Common Framework for Languages. The lesson was videotaped, and the video was transcribed using the transcription conventions GAT 2 (SELTING et al., 2011) and the software EXMARaLDA (SCHMIDT and WÖRNER, 2009). In this lesson, the teacher was asked to use a worksheet which was designed according to the cognitive approach proposed by Bellavia (2007). I selected two examples from the same exercise where the teacher and students are negotiating the meaning of über as a preposition and as a verbal prefix. Both meanings are metaphorical. In the analysis, however, I only offer the transcript of the sequences where the co-speech gestures for explaining über occurred, followed by a detailed description of these gestures. A complete transcript of each example can be read in the appendixes 1 and 2 .

The analysis of gestures was conducted based on the methodology proposed by Cienki (2010). I followed the basic four parameters for gesture's form (MITTELBERG, 2007 apud CIENKI, 2010), namely handshape, palm orientation, location of the gesture in space (in relation to speaker's body), and movement of the hand, using the following abbreviations: right open hand $(\mathrm{ROH})$, closed right hand $(\mathrm{CRH})$, left open hand $(\mathrm{LOH})$, left closed hand $(\mathrm{LCH})$, both hands $(2 \mathrm{H})$, stretched fingers (SF), palm up (PU), palm down (PD). A brief description of the gestures is given in the transcription. A more detailed description with pictures is made further in the analysis. Since I analyzed gestures that were used to explain the metaphorical concept conveyed by the preposition and verbal prefix über, only referential gestures with abstract references (MÜLLER, 1998 apud MÜLLER and CIENKI, 2009) were taken into consideration.

\subsection{Example 1: über as a preposition}

In the following sequence, a native German speaking teacher discuss with his Brazilian students the possible meanings for the preposition über in the sentence Er hat über 500 Euro (He has more than 500 Euros). The teacher has previously announced that über can be used as a preposition or as a verbal prefix and during the task students should try to explain the its meaning.

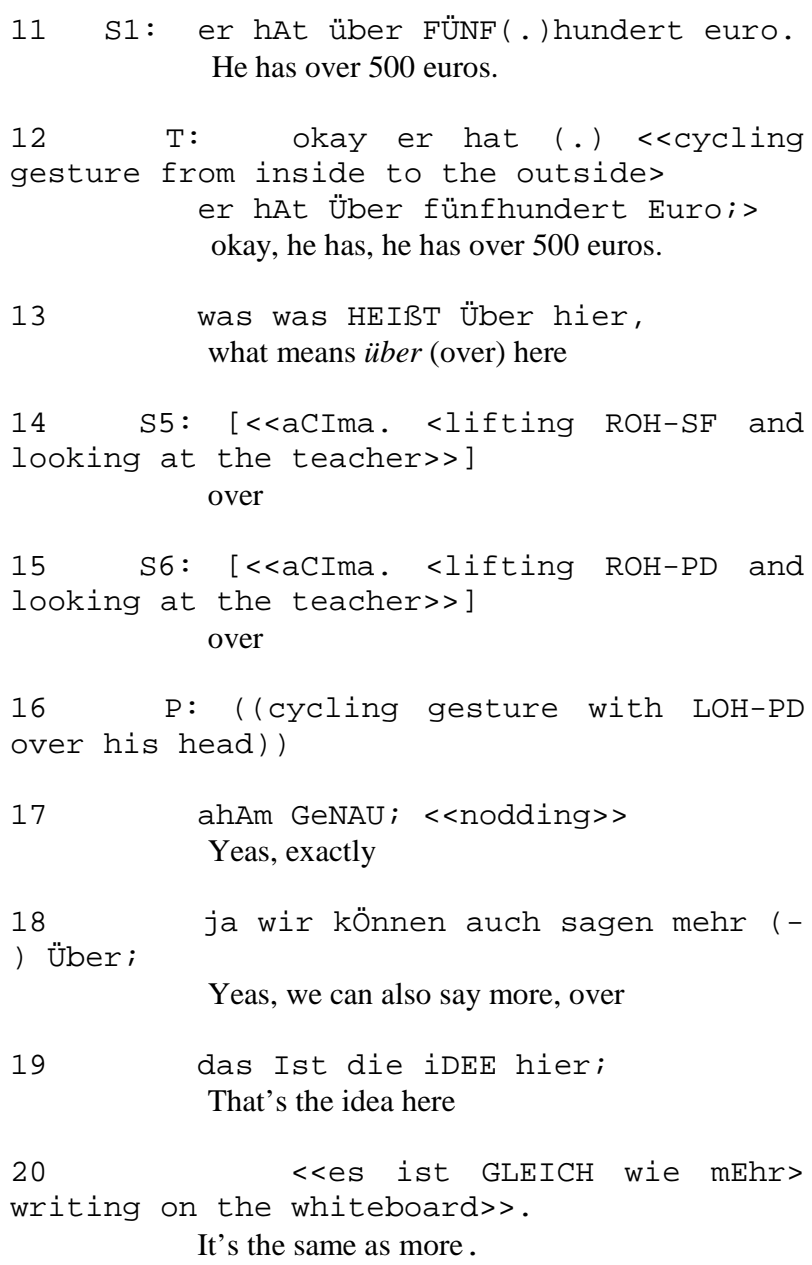

In line 13 he explicitly asks the meaning of this preposition in the example sentence and two students answered assertively, showing that they do understand the sentence. Both students' and 
teacher's speech are accompanied by similar gestures and we see in lines 14, 15 and 16.

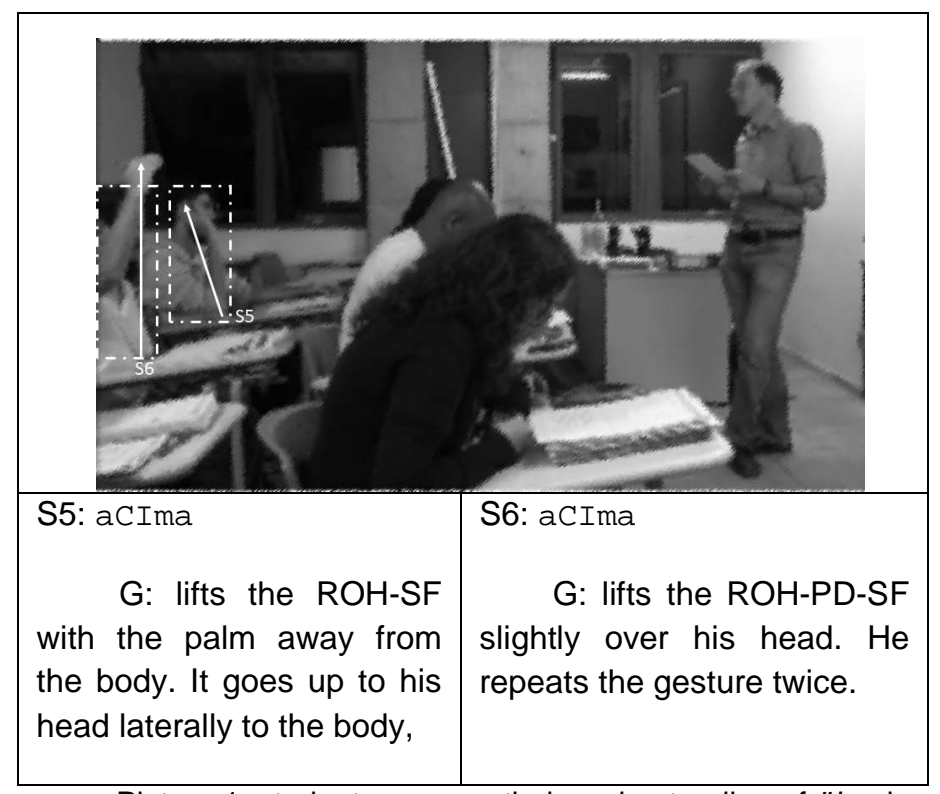

Picture 1: students express their understanding of über in the sentence Er hat über 500 Euro.

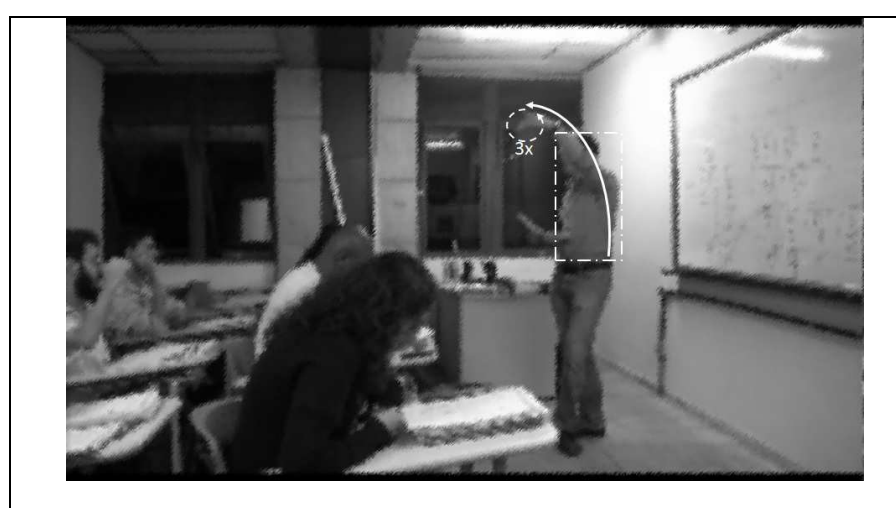

Teacher: ( (nodding to S5 and S6))

G: lifts LOH-PD over his head then makes outwards cycling gesture, repeating it quickly three times.

Picture 2: teacher agrees with students about the meaning of über in the sentence Er hat über 500 Euro.

The gestures produced by the teacher, as well as by the students, are a representation of the metaphorical meaning embedded in the preposition über, with the gesture stroke of S5 and S6 coinciding with the uttering of the Portuguese translation of über "acima". In the sentence, this preposition does not actually mean over (physically), but rather "more than" (quantity). This metaphorical meaning is motivated by conceptual metaphor MORE IS UP. Such primary metaphor comes from basic experiences in our daily lives. "If you add more of a substance or of physical objects to a container or pile, the level goes up" (LAKOFF; JOHNSON, 2013, p.16). In this case, the teacher's and students' gestures depicts the very DOWN-UP scheme of that is presented in the source domain of this experiential based metaphor. Lakoff (1987, p. 286) points out that the source domain VERTICALITY is directly mapped onto the target domain QUANTITY.

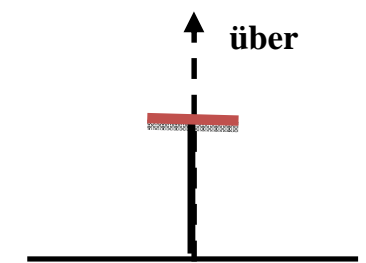

Picture 3: DOWN-UP scheme presented in the source domain of MORE IS UP which is depicted by the students' and teacher's gesture.

Müller and Cienki (2014, p. 1770) have already pointed out that "the Target Domain idea is represented by a gestural expression of the Source Domain idea for understanding it." Therefore, when both teacher and students make a gesture while they say "über" they are producing a multimodal metaphor, that is, a metaphor that occurs in both speech and gesture. As multimodal metaphors are usually produced when speakers want to reinforce the metaphor, one can say that teacher is drawing students' attention to the very meaning of über in that sentence, as well as students are confirming their understanding of it. The confirmation is reinforced by other interactional elements, such as teacher nodding in accordance while students S5 and S6 keep eye contact with him. The meaning is, thus, negotiated through the interaction in the classroom, rather than just taught by the teacher.

\subsection{Example 2: verbal prefix in überfliegen}

In this sequence, which is part of the same task, students and teacher discuss the meaning of the verb überfliegen (skim over), in the sentence Der Student hat den Text rasch überflogen (The student has quickly skimmed over the text). This verb is a 


$$
\begin{array}{r}
023 \mathrm{~T}: \text { das ist ganz SCHNELL, } \\
024 \text { (.) ein tExt lesen; } \\
\text { It is "to read a text very fast" }
\end{array}
$$

(.) genau;

$$
\text { (--) das heißt ÜBERfliegen }
$$

This means überfliegen, that's it.

$$
\begin{aligned}
& 026 \text { S8: ah; } \\
& 027 \text { T: das ist metapHOrisch; } \\
& \\
& \quad \text { That's metaphorical }
\end{aligned}
$$

028 das ist nichts hat nIchts mit dem FLUGzeug zu tun?

There is nothing to do with the airplane.

$$
<<p>j a,
$$

In lines 21 and 22, Student S8 asks if the meaning of the verb is leitura dinâmica (speed reading), a neurolinguistic reading methodology that used to be popular in Brazil and helps a reader to read a large amount of reading in only a few hours.

(BARBOSA, 2015) analyzed this sequence from a non-interactional and only a verbal perspective. She explained that überfliegen might be a dead metaphor to the German-native-speaker teacher, as he failed to realize metaphorical aspects of über in the verb. Although he admitted, in line 27 , that the verb is metaphorical, he failed to reconstrue this metaphoricity to his students, since he states, in line 28, that this example has nothing to do with the "airplane". The example Das Flugzeug fliegt über die Stadt (the airplane flies over the city) had been already discussed earlier in the lesson.

Nevertheless, when the same sequence is analyzed from an interactional-multimodal perspective, one can see that the teacher, in fact, embodies the meaning of the prefix über. When explaining the verb in lines 17, 18 and 19, he repeats the same explanation verbally (ganz schnell - very fast), but he does not repeat the same gesture. In line 19, he moves his LOH-PD-SF from right to the left over the worksheet, depicting the typical imageschema of über as an inseparable verbal prefix.

In this image-schema, the TR overcomes a LM that is seen in its entirety. The path crossed by TR as well as the morphological structure - is uninterrupted and extends over the entire surface of the LM (BELLAVIA, 2007, p. 138). According to Bellavia (2007, p. 140), the figurative expression einen Text überlesen (to skim over a text) is a linguistic metaphor which derivates from the conceptual metaphor SEEING IS TOUCHING (LAKOFF; JOHNSON, 2013 [1980]). One can say, thus, that the gesture made by the teacher in line 19 is a monomodal metaphor of the verb überfliegen, since it occurs only in the visual/spatial modality. The gesture represents the image-schema of the source domain in SEEING IS TOUCHING. However, as previously discussed, the metaphor is monomodal and, hence, not cognitively activated in the interaction. This is an empirical evidence that, although the German-native-speaker teacher does have this meaning embodied, he did not activate this metaphorical aspect during interaction and, consequently, did not make it clear to students.

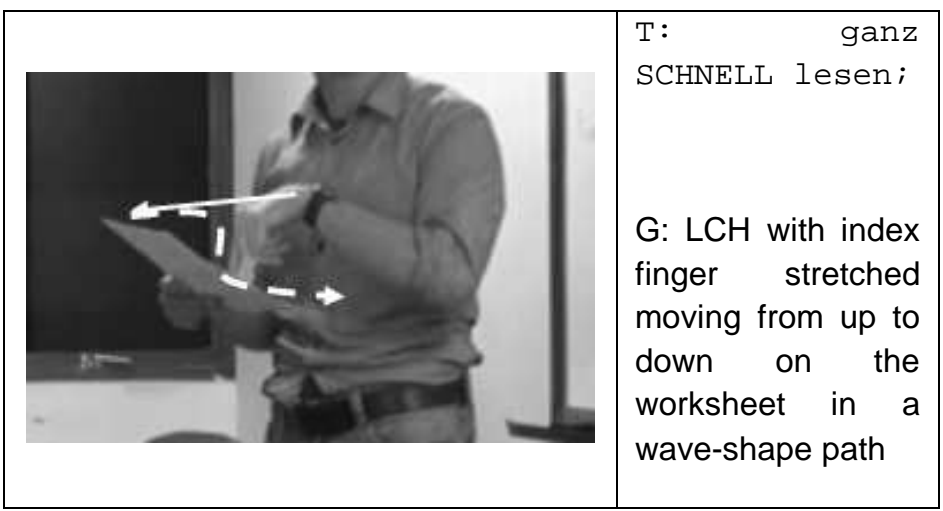

Picture 5: first gesture for ganz schnell in line 17.

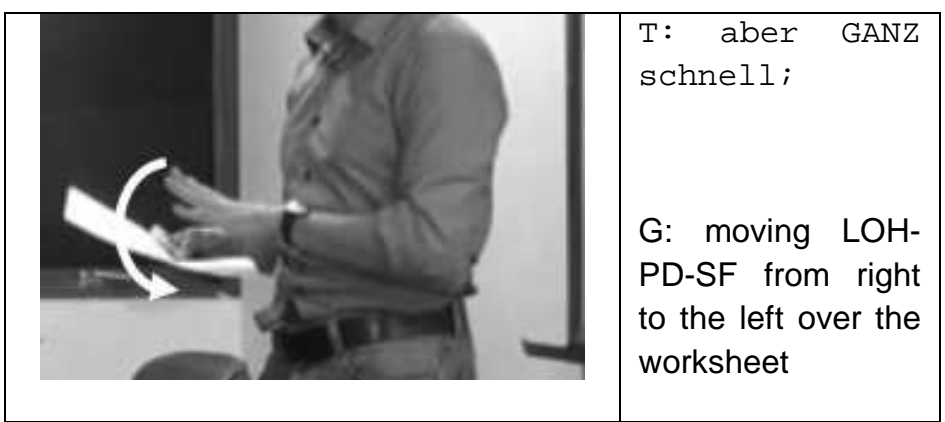

Picture 6: second gesture for ganz schnell in line 19. 


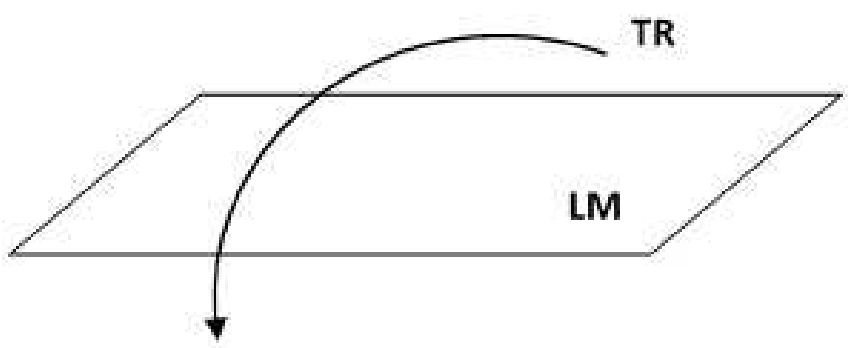

Picture 7: typical use of über as a verbal prefix (adapted from BELLAVIA, 2007, p.138)

Bellavia (2007) compares, for instance, the literal sentence Das Flugzeug überflog den Ozean (the airplane flew over the ocean) to the metaphorical sentence Er überflog rasch den Text (he quickly skimmed over the text) and explains:

The process of reading quickly is seen as the eyes flying over the text. Since the reader wants to grasp the global meaning of the text, they observe the surface of the text quickly, without 'going through it'. That is, not stopping at any point in the essay. The text is perceived as a limited region in the space (we say in German 'field of vision') that is crossed by the reader as well as their eyes. (BELLAVIA, 2007, p. 140-141).

Making this analogy could be a more suitable alternative to explaining überfliegen. (BARBOSA, 2015) showed how a Brazilian teacher and advanced speaker of German, who worked with the same worksheet, proposed to his students this analogy. He drew the student's attention to the fact that one flies over a text to have a panoramic or broad view of it (getting its main idea), as well as one has a panoramic view of a city when flying over it in an airplane, for example. His explanation was accompanied by gestures and this visual aid made the metaphor clearer to students.

Nevertheless, it is not the aim here to discuss why the German-teacher did not activate this metaphor verbally or visually. As Müller and Tag (2010) explain, activating metaphoricity is an interactional process that involves different cognitive strategies throughout the conversation. I believe that the analysis could reveal this process, but it cannot reveal the reasons for doing it, though. In the next session, I will comment briefly on the analysis results and its possible pedagogical implications.

\section{Conclusion}

The analyses show how conceptual fluency can be a determining factor to mastering a foreign language. The two brief multimodal analyses of teacher-student interactions revealed to us how metaphorical thinking is indeed embodied and how such embodiment can be explored in the classroom. Our first case showed how the access to the primary metaphor MORE IS UP helped the students to understanding the metaphorical meaning of über in the sentence Er hat über 500 Euro, which was confirmed by their gestures. On the other hand, as the students did not have access to the metaphorical conceptualizations underneath the concept of überfliegen, a situation of misunderstanding takes place instead of an opportunity for meaning negotiation, since the students understood only partially the meaning of the verb (überfliegen is understood as speed reading).

Therefore, having access to the conceptualizations that relies underneath metaphors is crucial to understand not only idioms, but verbs and expressions that occurs very often in a language. Moreover, applying a multimodal perspective to the analysis of teacher-learner interaction in the classroom helped us to describe not only the process of meaning negotiation during these interactions, but also to reveal the metaphorical thinking happening online during the time of conversation, for the gestures produced by teacher and learners, which gives us access to the metaphor process (MÜLLER and CIENKI, 2009; MÜLLER and TAG, 2010).

In addition, Bellavia (2007, p. 330) points out the importance of teachers providing their students with visual aids to illustrate possible cognitive aspects of lexical items, such as the metaphorical mappings. Therefore, the analysis can also help to think how gestures can be introduced in the Foreign Language Teaching as a kind of visual aid. Explaining to the 
teachers about these strategies, along with a reflection about semantic aspects of the $L 2$, can help translate theories, such as the dynamicity of metaphoricity into more effective pedagogical strategies for teaching metaphors.

\section{Referências}

BARBOSA, Adriana Fernandes. O papel da linguística cognitiva na formação do professor de alemão como língua estrangeira: um estudo sobre 0 ensino da preposição über com base em esquemas imagéticos e metáforas conceptuais. Dissertação (mestrado) - Universidade Federal de Minas Gerais, Faculdade de Letras, Belo Horizonte, MG. 2015.

BELLAVIA, Elena. Erfahrung, Imagination und Sprache: die Bedeutung der Metaphern der Alltagssprache für das Fremdsprachenlernen am Beispiel der deutschen Präpositionen. Giessener Beiträge zur Fremdsprachendidaktik. Tübingen: Gunter Narr, 2007.

BOERS, Frank; LINDSTROMBERG, Seth. Cognitive Linguistic Approaches to Teaching Vocabulary and Phraseology. Berlin: Mouton de Gruyter, 2008.

DANESI, M. Learning and teaching languages: the role of "conceptual fluency". International Journal of Applied Linguistics, 5, 1995, p. 3-20.

GRASS, Anja. Zur Veränderung mentaler Modelle beim Lernen mit Grammatikanimationen: Ziele, Methoden und Ergebnisse einer Pilotstudie. Zeitschrift für interkulturellen Fremdsprachenunterricht, Darmstadt, v. 18, n. 1, p. 99-109, abr. 2013.

CIENKI, Alan. Multimodal metaphor analysis. In: CAMERON, Lynne and MASLEN, Robert eds. Metaphor Analysis: Research Practice in applied Linguistics, Social Sciences and the Humanities. Studies in Applied Linguistics. London: Equinox, 2010, p. 195-214.

CIENKI, Alan; MÜLLER, Cornelia. Ways of viewing metaphor in gesture. In: MÜLLER, Cornelia et al. Body - Language - Communication. An International Handbook on Multimodality in Human Interaction, vol. 2, Berlin, Boston: De Gruyter Mouton, 2014, p. 1766-1781.

LANGACKER, Ronald W. Foundations of cognitive grammar: theoretical prerequisites, v.1, Stanford, CA: Stanford University Press, 1987.

LANGACKER, Ronald W. Foundations of cognitive grammar: descriptive application, v.2, Stanford, CA: Stanford University Press, 1991.
LITTLEMORE, Jeannette; LOW, Graham. Figurative thinking and foreign language learning. New York: Palgrave Macmillan, 2006.

LITTLEMORE, Jeannette. The relationship between associative thinking, analogical reasoning, image formation and metaphoric extension strategies. In: ZANOTTO, Mara Sophia; CAMERON, Lynne; CAVALCANTI, Marilda C. (Ed). Confronting Metaphor in Use. An applied linguistic approach. Amsterdam, Philadelphia: John Benjamins, 2008, p. $199-222$.

LITTLEMORE, Jeannette. Applying Cognitive Linguistics to Second Language Learning and Teaching. Basingstoke/New York: Palgrave Macmillan, 2009

LOW, Graham D. On teaching metaphor. Applied Linguistics, Oxford, v. 9, n. 2, p. 125-47, 1988.

MÜLLER, Cornelia; CIENKI. Alan. Words, gestures, and beyond: Forms of multimodal metaphor in the use of spoken language. In FORCEVILLE, Charles; URIOS-APARISI, Edurado (eds.), Multimodal Metaphor. Berlin \& New York: Mouton de Gruyter, 2009, p. 297-328.

MÜLLER, Cornelia; TAG, Susanne. The Dynamics of Metaphor: Foregrounding and Activating Metaphoricity in Conversational Interaction. Cognitive Semiotics 6, 2010, p. 85-120.

PICKEN, J. Literature, Metaphor and the Foreign Language Learner. Basingstoke/New York: Palgrave Macmillan, 2007.

RADDEN, Günter. Konzeptuelle Metaphern in der kognitiven Semantik. In: BÖRNER Wolfgang; VOGEL, Klaus (ed.). Kognitive Linguistik und Fremdsprachenerwerb: das mentale Lexikon. Tübingen: Gunter Narr Verlag, 1994, p. 69-87.

ROCHE, Jörg; SCHELLER, Julija. Zur Effizienz von Grammatikanimationen beim Spracherwerb: ein empirischer Beitrag zu einer kognitiven Theorie des multimedialen Fremdsprachenerwerbs. Zeitschrift für Interkulturellen Fremdsprachenunterricht, Darmstadt, v. 9, n. 1, 114, 2014.

SELTING, Margret at al. A system for transcribing talk-in-interaction: GAT 2. Tradução de, Elizabeth Couper-Kuhlen e Dagmar Barh-Weingarten. Gesprächsforschung - Online-Zeitschrift zur verbalen Interaktion, Mannheim, v.12, 1-51, 2011.

SCHELLER, Julija. Animationen in der Grammatikvermittlung: multimedialer Spracherwerb am Beispiel von Wechselpräpositionen. Berlin: LIT, 2008.

SCHMIDT, Thomas; WÖRNER, Kai. EXMARaLDA. Creating, analysing and sharing spoken language corpora for pragmatic research. Pragmatics, International Pragmatics Association, v. 19, 565582, 2009. 
SCHRÖDER, Ulrike. Multimodal metaphors as cognitive pivots for the construction of cultural otherness in talk. Intercultural Pragmatics, 14 (4), 2017, pp. 493-524.

\section{Appendix 1 - sentence Er hat über 500 Euro}

01 T: und das ist MANCHmal die präpositio:n (-) Über, and sometimes is the prespostion über

02 manchmal das IST aber auch ahm: ein prë:fix;

But sometimes is also a prefix

03

ein VERB na?

A verb, right?

04 schAuen wir mal erstens zuSAMmen (.) diese sätze an,

let's first take a look at this sentence

05 versuchen wir mal es zu verSTEhen,

let's try to understand

06 was das beDEU:tet.

What it means

$07 \quad<$ pointing to the student S1>

S1 du

mAchst satz EINS.>

S1 you do sentence one

08 S1: ahm?

09 T: einfach lEsen (.) SATZ eins;

Simply read the sentence one

10 hier. (lnoints with index

finger to the workshe $\epsilon$

Here

26

11 S1: er hAt über $\operatorname{FÜNF}($. ) hundert euro.

He has over 500 euros.

12 T: okay er hat (.) <<cycling gesture with the right hand from inside and stretched fingers to the outside> er hAt Über fünfhundert

Euro; $>$

okay, he has, he has over 500 euros.

13

was was HEIßT Über hier,

what means über (over) here

14 S5: [<<aCIma. <lifting ROH-SF and looking at the teacher $>>$ ]

over
15 S6: [<<aCIma. <lifting ROH-PD and

looking at the teacher $>>$ ]

over

16 P: (lcycling gesture with LOH-PD over his head))

17 ahAm GeNAU; <<nodding >>

Yeas, exactly

18 ja wir kÖnnen auch sagen mehr

(-) Über;

Yeas, we can also say more, over

19 das Ist die iDEE hier;

That's the idea here

es ist GLEICH wie mEhr.

It's the same as more.

\section{Appendix 2 - sentence Der Student hat den Text rasch überflogen}

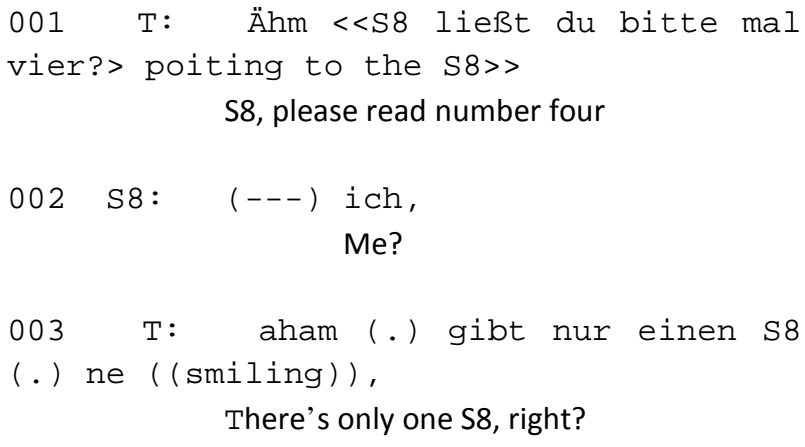

S8, please read number four

002 S8: (--) ich,
Me?

003 T: aham (.) gibt nur einen S8

(.) ne ((smiling)),

There's only one $\mathrm{S} 8$, right?

004 S8: der STUDent hat den text rAsch Überflogen;

27

-' . ' has quickly skimmed over the

005 T: mh ((schnalzt mit der zunge));

006 (--)okay (.) das ist SEHR

metapho:risch,

Okay, that's very metaphorical

007 (-) stuDENT ist klar?
"student" is clear
008 : $\begin{aligned} & \text { jA; } \\ & \text { Yes }\end{aligned}$
009 TEXT ist klar?
"text" is clear
das Proble:m,

Now there's, maybe, the problem 
011 mit dem VERB überfIEgen; With the verb überfliegen (skim over)

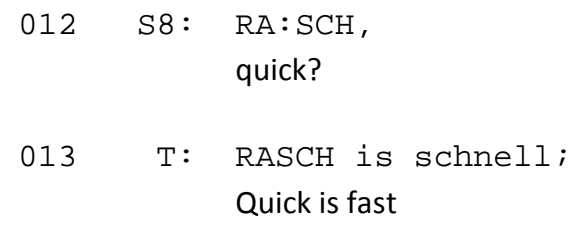

Not precisely, not exactly.
$019<($.) aber GANZ schnell; > moving LOH-PD-SF from right to the left

over the worksheet $>>$

But very fast.

020 das heißt (.) wa:s für eine iDEE haben wir mit Über hier,

That means... what kind of meaning does über have here?

021 S8: dyNAmik lektÜre, "Dynamic reading" seri:a leitura diNAmica (-) algo,

Would that be speed reading?

$023 \mathrm{~T}:$ das ist ganz SCHNELL,
024 (.) ein tExt lesen;
It is "to read a text very fast"
(--) das heißt ÜBERfliegen (.) genau;

This means überfliegen, that's it.

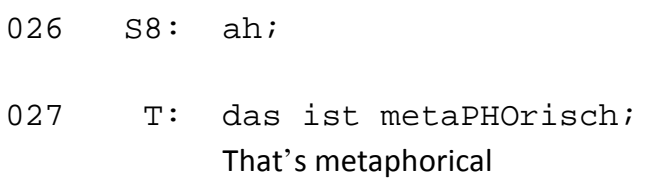

028 das ist nichts hat nIchts mit dem FLUGzeug zu tun?

There is nothing to do with the airplane. $<<\mathrm{p}>\mathrm{ja}$, Right?

\section{COMO CITAR ESSE ARTIGO}

BARBOSA, Adriana Fernandes. Cognition in (inter)action: multimodal metaphors produced during a lesson of German as a Foreign Language. Signo, Santa Cruz do Sul, v. 44, n. 79, jan. 2019. ISSN 1982-2014. Disponível em: <https://online.unisc.br/seer/index.php/signo/article/view/12713>. Acesso em doi: https://doi.org/10.17058/signo.v44i79.12713 